\title{
10. DEVELOPMENT OF REDUCTION HALOES UNDER CALCAREOUS AND VOLCANICLASTIC TURBIDITES IN THE LAU BASIN (SOUTHWEST PACIFIC) ${ }^{1}$
}

\author{
J. Thomson, ${ }^{2}$ R.G. Rothwell, ${ }^{2}$ and N.C. Higgs ${ }^{2}$
}

\begin{abstract}
The sediment column overlying basement in the Lau Basin consists of a sequence of volcaniclastic turbidites interbedded with hemipelagic clayey nannofossil mixed sediments, overlain in turn by a sequence of hemipelagic clayey nannofossil oozes containing sporadic calcareous turbidites. The clayey nannofossil oozes and mixed sediments are pervasively stained by hydrothermally derived iron and manganese oxyhydroxides. Sharply defined, lighter colored bands occur in the hemipelagic sediments, immediately beneath some (but by no means all) volcaniclastic and calcareous turbidites. These are identified as reduction haloes, of a type previously identified in quite different turbidite/pelagic sequences. The haloes are attributed to the burial of labile surficial $\mathrm{C}_{\mathrm{org}}$ by turbidites, followed by the remineralization of this $\mathrm{C}_{\mathrm{org}}$ with $\mathrm{Mn}$ and Fe oxyhydroxides as electron acceptors. The resultant characteristic $\mathrm{Mn}$ and Fe concentration/depth profiles are described, and a model is proposed for their development. The color alteration of the halo is ascribed to the removal of Mn oxyhydroxides, because, although the Fe content fluctuates through the haloes, this does not appear to affect their color. Other elements $(\mathrm{Co}, \mathrm{Cu}$, and $\mathrm{Ni}$ ) are also at low concentration levels in the haloes like $\mathrm{Mn}$, consistent with remobilization and migration out of the halo section, although the profile shapes are not identical with those of $\mathrm{Mn}$. The behavior of $\mathrm{V}$ is distinctive in that it appears to have migrated into the haloes to be enriched there. Haloes are unlikely to form if turbidite emplacement is erosive and removes the near-surface layer, which generally is the most fluid part of the sediment and contains the highest levels of reactive $\mathrm{C}_{\mathrm{org}}$ to drive the reduction process. Conversely, the presence of a halo implies that emplacement of the overlying turbidite did not significantly erode the pre-existing sediment/ water interface.
\end{abstract}

\section{INTRODUCTION}

Deep-sea cores often reveal that turbidites are an important component of basin plain sediments; indeed, such redeposited sediments can dominate sediment accumulation over long periods of time. Thus, turbidite sedimentology is an active research area, but little account is generally taken of postdepositional, early diagenetic effects. Such geochemical reactions can produce readily recognizable alterations, particularly to sediment color, which can be a useful diagnostic tool in core interpretation. One example is the progressive oxidation front, in which bottom-water oxygen modifies the tops of turbidite units and causes marked color changes (Jarvis and Higgs, 1987; Thomson et al. 1987).

A different observation frequently made during shipboard core description of cores from the Lau backarc basin on Ocean Drilling Program (ODP) Leg 135 was the presence of lighter colored bands immediately beneath some turbidite units. These lighter colored sediments, which had a very sharp lower boundary, were not present elsewhere in the same cores, and were reminiscent of the "reduction haloes" investigated in Atlantic brown clays by Thomson et al. (1989). It is important to identify features that are the result of diagenetic reactions rather than primary sedimentary features for core description and stratigraphic assessment. Consequently, we report an investigation into the nature of these lighter colored bands and their significance.

\section{SEDIMENTATION IN THE LAU BASIN}

The western Lau Basin, between the central and eastern Lau spreading centers and the Lau Ridge, contains several small, elongate, fault-bounded, sediment-filled sub-basins. Sites 834 and 835 were drilled in two of these basins between 100 and $200 \mathrm{~km}$ east of the axis of the Lau Ridge, whereas Sites $836,837,838$, and 839 were drilled

\footnotetext{
${ }^{1}$ Hawkins, J., Parson, L., Allan, J., et al., 1994. Proc. ODP, Sci. Results, 135: College Station, TX (Ocean Drilling Program).

${ }^{2}$ Institute of Oceanographic Sciences, Brook Road, Wormley Near Godalming, Surrey GU8 5UB, United Kingdom.
}

in small basins much closer to the East Lau Spreading Center (ELSC; Fig. 1). The sediment column overlying the basement basalts at all sites consists primarily of a lower sequence of volcaniclastic turbidites interbedded with hemipelagic clayey nannofossil mixed sediments and nannofossil clays; this in turn is overlain by an upper sequence of hemipelagic clayey nannofossil oozes that sometimes contain calcareous turbidites. The thicknesses of both the volcaniclastic turbidite sequence and the overlying clayey nannofossil ooze sequence are variable.

The clayey nannofossil oozes and mixed sediments at all sites are pervasively stained reddish brown to yellowish brown by hydrothermally derived iron and manganese oxyhydroxides. These occur as small aggregates within the sediments and as surface coatings around the sedimentary grains. Hydrothermally derived iron and manganese oxyhydroxides are widely distributed throughout the sediments of the Lau Basin (Cronan et al., 1986; Hodkinson et al., 1986; Reich et al., 1990). Typically, the clayey nannofossil oozes are stained brown to dark yellowish brown, having Munsell color values and chromas within the hue 10YR. Typical colors are moderate (10YR 5/4) to dark yellowish brown (10YR 4/2).

Frequently, bands of lighter color occur in the clayey nannofossil sediments directly beneath turbidite bases. These lighter colored bands occur under both calcareous and volcaniclastic turbidites, but they are not universal, frequently being quite rare in many of the interbedded turbidite/hemipelagite sequences. They occur at all the backarc sites, although they are more common in the sediment sequences at Sites 837 and 839. Typical colors of these lighter bands are moderate yellowish orange (10YR $6 / 6$ to $10 \mathrm{YR} 6 / 4$ ) to moderate yellowish brown (10YR $5 / 4)$. Their lower boundaries with the darker clayey nannofossil ooze are sharp and the bands contrast with the underlying sediment, varying in thickness from a few millimeters up to $88 \mathrm{~cm}$. The thickness of these lighter bands is independent of the thickness of the overlying turbidite and of the thickness and coarseness of any basal sand. Even under very thick turbidites, they are never more than $1 \mathrm{~m}$ thick.

These lighter colored bands present beneath turbidites are strongly reminiscent of the "reduction haloes" investigated in Atlantic brown clays by Thomson et al. (1989). The sediment types in these two cases 


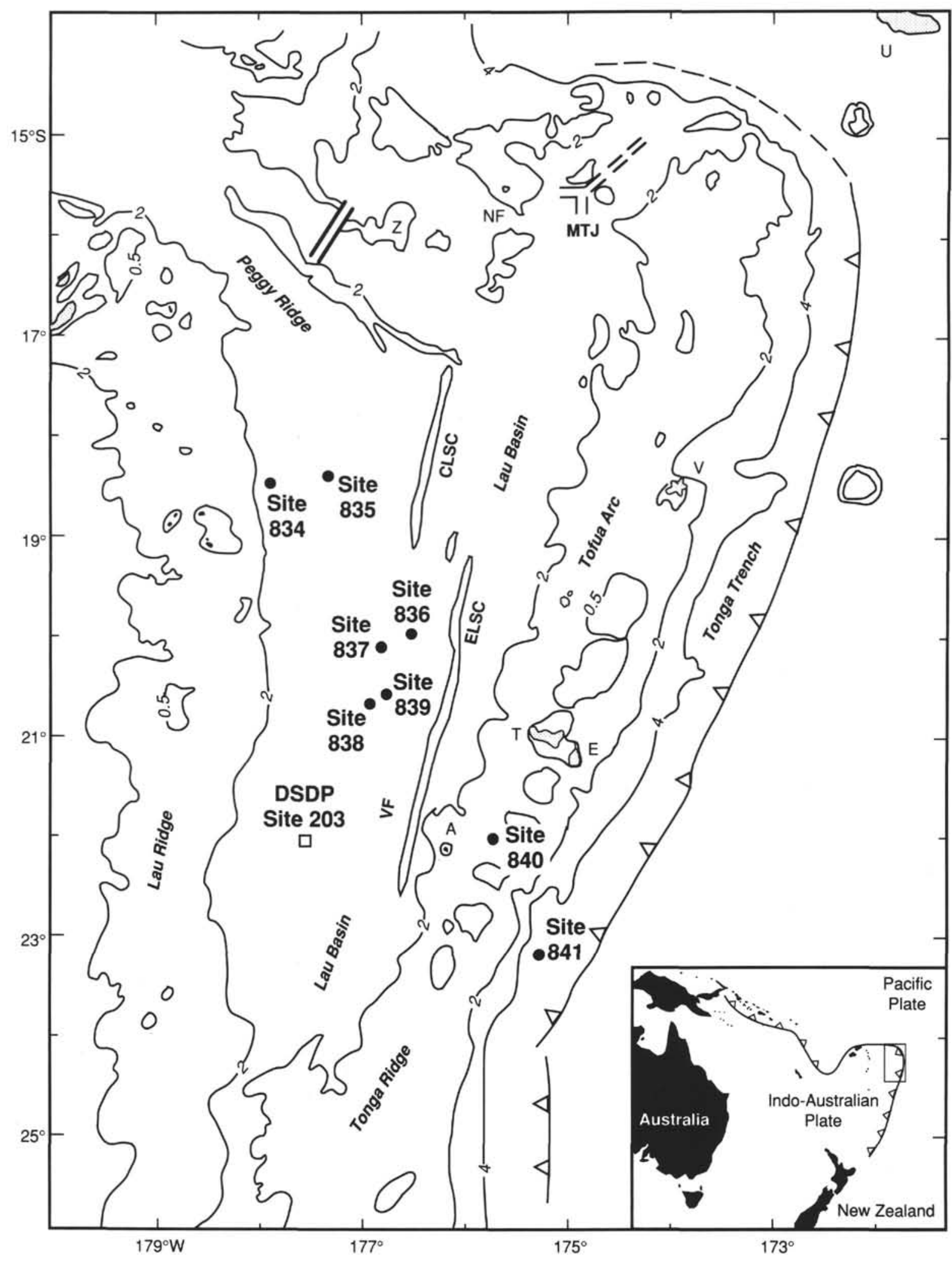

Figure 1. Location of ODP sites drilled in the Lau Basin, Western Pacific, during Leg 135. Also shown are the main geological features of the Tonga Trench and Lau Basin system. Islands shown are Tongatapu (T), 'Eua (E), Vava'u (V), Niuafo'ou (NF), 'Ata (A), and Upolu (U), Locations of the Central Lau (CLSC) and East Lau (ELSC) spreading centers, Valu Fa Ridge (VF), Mangatolu Triple Junction (MTJ), and Zephyr Shoal (Z) are also shown. 
are entirely dissimilar, however. The brown clay reduction haloes occurred in the sediments of the Nares Abyssal Plain, which comprise slowly accumulated brown clays interbedded with turbiditic grey clays. Both clay types had a similar mineralogical composition with a negligible carbonate content, and the color differences were found to be the result of different $\mathrm{Mn}$ and $\mathrm{Fe}$ contents and redox status. Such clays are quite unlike the Lau Basin sediments, which are considerably more complex compositionally. Thomson et al. (1989) ascribed the reduction haloes in the Nares sediments to the burial of labile surficial $\mathrm{C}_{\text {org }}$ by turbidites, followed by the oxidation of this $\mathrm{C}_{\text {org }}$ with $\mathrm{Mn}$ and $\mathrm{Fe}$ oxyhydroxides as electron acceptors after the original pore-water oxygen was exhausted. This process will be discussed in more detail below, but it seems likely that the burial of the labile $\mathrm{C}_{\mathrm{org}}$ at former sediment surfaces by turbidites is the link in the two contrasting situations. For different reasons, the nonturbiditic sediments of both areas have substantial $\mathrm{Mn}$ and $\mathrm{Fe}$ oxyhydroxide contents to act as electron acceptors. This study was undertaken to investigate this interpretation and the pattern of diagenetic relocation of elements within the haloes.

\section{METHODS}

Two vertical profiles through the lighter colored bands beneath a calcareous turbidite (in Section 135-834A-2H-1; Fig. 2) and a volcaniclastic turbidite (in Section 135-837A-8H-2; Fig. 3) were sampled. Each example was sampled from above the base of the turbidite, through the lighter colored band, and down into the darker clayey nannofossil ooze below. In both cases, the turbidites were chosen for their relative thickness $(>3.5 \mathrm{~m})$ and for the thickness of the lighter colored bands beneath them $(15-20 \mathrm{~cm})$.

For each profile, 25 samples were taken, about 1-2 cm apart, using 5 -ml capacity syringes of $1-\mathrm{cm}$ diameter to extract $2-\mathrm{cm}^{3}$ samples of wet sediment, which gave a dry sample mass of approximately $1 \mathrm{~g}$. Thus, sampling was at the maximum allowed ODP sampling density $\left(50 \mathrm{~cm}^{3} / \mathrm{m}\right.$ removed from the core). The samples were dried at $110^{\circ} \mathrm{C}$ and ground manually in agate. Aliquots of $0.5 \mathrm{~g}$ were dissolved in $\mathrm{HF} / \mathrm{HClO}_{4}$, heated to near dryness, redissolved in $5 \mathrm{ml} 5 \mathrm{~N} \mathrm{HNO}_{3}$, and diluted to $50 \mathrm{ml}$ with double distilled water for simultaneous ICP-AES analysis (Totland et al., 1992). The elements $\mathrm{Al}, \mathrm{Fe}, \mathrm{Mn}, \mathrm{Mg}, \mathrm{Na}, \mathrm{K}$, $\mathrm{Ti}, \mathrm{Co}, \mathrm{Cu}, \mathrm{Ni}, \mathrm{Sc}, \mathrm{Sr}, \mathrm{V}, \mathrm{Y}, \mathrm{Zn}$, and $\mathrm{P}$ were determined. Precision ranged from $2 \%$ to $5 \%$ for all elements except $\mathrm{P}_{2} \mathrm{O}_{5}$ and $\mathrm{Sc}(6 \%)$. Accuracy was assessed by analysis of USGS standard basalt BHVO-1 (see Table 2). Calcium carbonate analyses were performed using the Coulometrics analyzer on the $\mathrm{CO}_{2}$ released from $25-\mathrm{mg}$ samples by acid treatment. Precision for carbonate analysis was better than $1 \%$ relative.

\section{RESULTS AND DISCUSSION}

The two core sections investigated (Figs. 2 and 3) show minor coring distortion of the interface between the base of the turbidite and the top of the underlying sediment; in both, the lower limit of the light-colored sediment is sharply defined. The lighter color of the calcareous turbidite in Section 135-834A-2H-1 contrasts with the darker color of the volcaniclastic turbidite in Section 135-837A-8H-2. Compositionally, the hemipelagic clayey nannofossil ooze beneath the basal turbidite foraminiferal sand in Section 135-834A-2H-1 consisted of about $35 \%-40 \%$ clay, $5 \%$ foraminifers, and the remainder, calcareous nannofossils. The color of the lighter colored band directly beneath the calcareous turbidite in this core is very dark yellowish orange (10YR 5/6), whereas the clayey nannofossil ooze directly beneath the lighter colored band is very dark yellowish brown (10YR 3/4) (Fig. 2). In Section 135-837A-8H-2, the hemipelagic sediment directly below the volcaniclastic turbidite base consists of up to $50 \%$ clay and $5 \%$ foraminifers. The rest is composed of calcareous nannofossils and is considered to be a mixed sediment, according to the classification of Mazzullo et al. (1987). The lighter colored band in

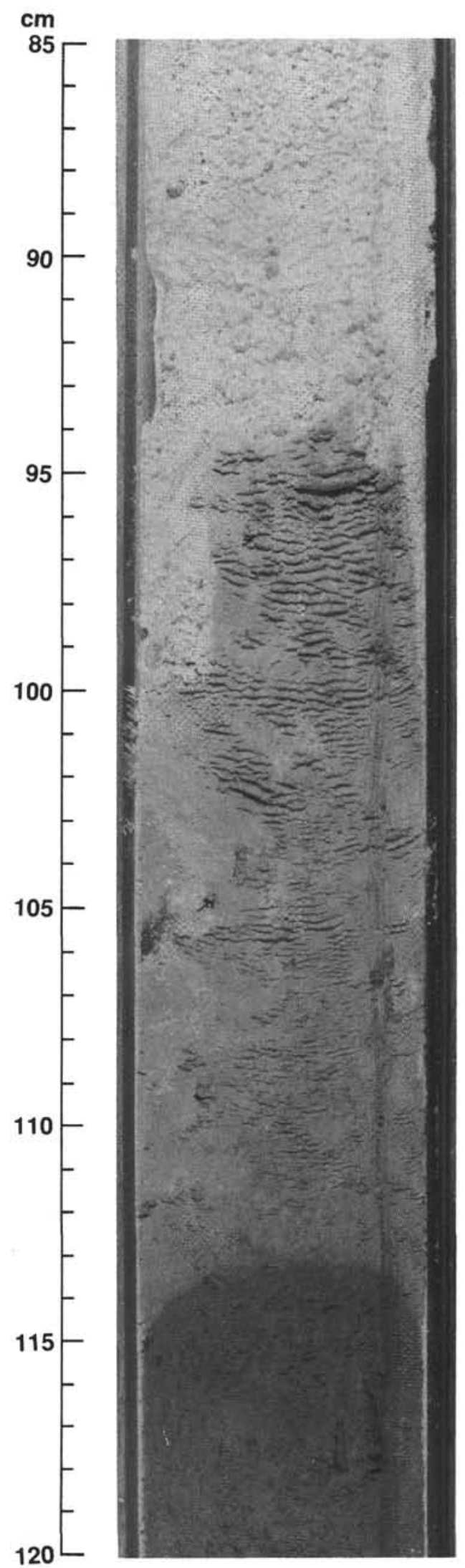

Figure 2. Lighter colored band beneath a thick calcareous turbidite in Section $135-834 \mathrm{~A}-2 \mathrm{H}-1$. The lighter colored band is dark yellowish orange (10YR 5/6) and contrasts with the much darker dark yellowish brown (10YR 3/4) clayey nannofossil ooze below. The lighter colored band is $19 \mathrm{~cm}$ thick. 


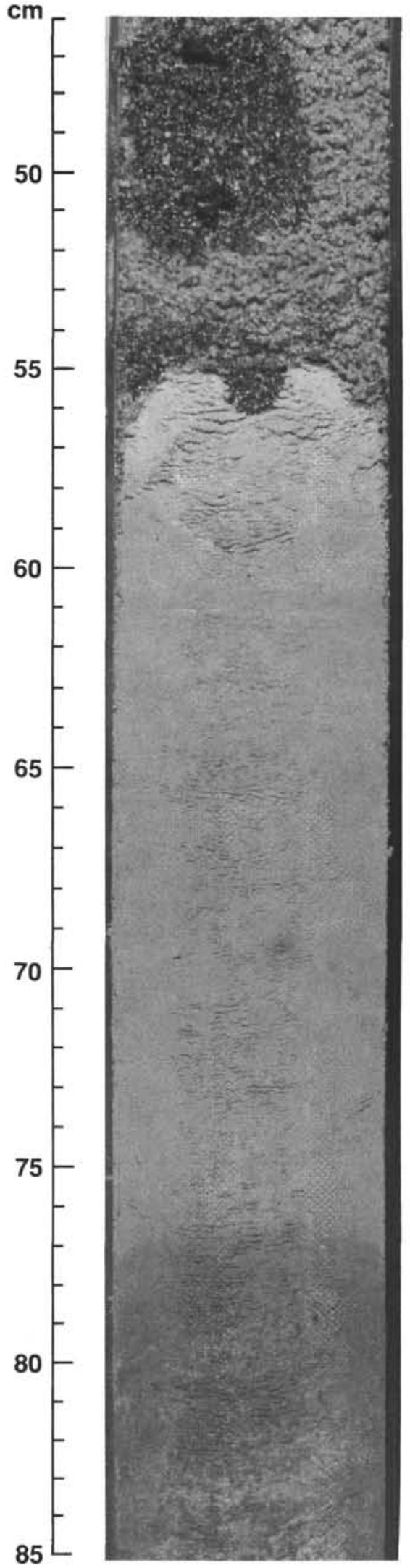

Figure 3. Lighter colored band beneath a thick volcaniclastic turbidite in Section 135-837A-8H-2. The lighter colored band is yellowish brown (10YR $6 / 4$ ) and contrasts with the much darker dark yellowish brown (10YR 4/3) clayey nannofossil ooze below. The lighter colored band is $22 \mathrm{~cm}$ thick. this core is light grayish orange (10YR 6/4), whereas the nannofossil clay mixed sediment directly below the lighter colored band is very dark yellowish brown (10YR 4/3) (Fig. 3).

Selected major and minor element concentration/depth profiles corresponding to the core sections of Figures 2 and 3 are shown in Figures 4 and 5 , and the complete data for all the elements measured are listed in Tables 1 and 2. The differences in the composition of the two turbidites in comparison with the underlying pelagic sediments are clear, with $\mathrm{CaCO}_{3}$ dominating the composition of the high magnesian calcite turbidite in Section 135-834A-2H-1 (Fig. 4), and high $\mathrm{Al}_{2} \mathrm{O}_{3}$ (and $\mathrm{TiO}_{2}$ ) characterizing the volcaniclastic turbidite in Section $135-837 \mathrm{~A}-8 \mathrm{H}-2$ (Fig. 5). The turbidite in Section 135-837-8H-2 shows some fluctuation in $\mathrm{Al}_{2} \mathrm{O}_{3}$ content, consistent with basal grading, as well as increased $\mathrm{Fe}_{2} \mathrm{O}_{3}$ coincident with the blue/black stain at $46-52 \mathrm{~cm}$ (66.94-67.00 mbsf) at the base of this turbidite (Fig. 5).

The underlying hemipelagic sediments in both cases contain around $50 \%-60 \% \mathrm{CaCO}_{3}$, and both also show compositional fluctuations (range: $48 \%-82 \% \mathrm{CaCO}_{3}$ ) with depth. These carbonate/noncarbonate fluctuations are a complication over the previously studied Nares cases (Thomson et al. 1989), where the pelagic clays were essentially carbonate-free and the geochemically inert elements had a uniform content. Some sediments can be approximated as a two-component system comprising biogenic $\mathrm{CaCO}_{3}$ and clay, and in such cases carbonate fluctuations can be overcome by expressing data on a carbonate-free basis because biogenic carbonate is essentially pure $\mathrm{CaCO}_{3}$. This technique is not appropriate here because the hemipelagic Lau Basin sediments also contain a third (hydrothermal) component. A further uncertainty for interpretation of the Lau Basin sediments is that the two sections investigated are only $30 \%$ sampled $(25 \times 1-\mathrm{cm}$ samples in 80 $\mathrm{cm}$ ), whereas the previous work (Thomson et al. 1989) sampled in contiguous $1-\mathrm{cm}$ increments and observed that redox-sensitive elements showed considerable local detail in their redistributions. The approach taken in the interpretation of the redox-sensitive element data of Sections 135-834A-2H-1 and 135-837A-8H-2, therefore, is to seek similarities first between their element concentration/depth profiles, and second with the three examples from the Nares Abyssal Plain previously investigated (Thomson et al., 1989).

\section{Behavior of $\mathrm{Mn}$ and $\mathrm{Fe}$}

Marked similarities are present between the profile shapes of Mn and Fe through the light-colored sediments in the two Leg 135 examples.

1. For example, consistently low Mn levels are present throughout the light-colored sediments in comparison with the underlying hemipelagic sediments. The slight increase in Mn content with depth in the light colored sediments in Section 135-834A-2H-1 is a consequence of the decreasing calcium carbonate content with depth (Fig. 4), whereas the Mn and carbonate contents in the light colored interval of Section 135-837A-8H-2 are essentially invariant (Fig. 5).

2. In addition, a more complex Fe shape occurs in the lightcolored sediments, with low values immediately below the turbidite, increasing with depth through a maximum, and then decreasing within the light-colored sediments. The Fe levels of the maxima in the light colored sediments are the highest observed in the two core sections (Figs. 4-6).

These general profile shapes for $\mathrm{Fe}$ and $\mathrm{Mn}$ are identical with those observed previously in the three Nares Abyssal Plain examples investigated (Thomson et al., 1989), and this is taken as justification for referring henceforth to the light-colored sediments as reduction haloes. The model developed from the Nares examples envisaged that, in the absence of $\mathrm{O}_{2}$ after turbidite emplacement, all available $\mathrm{Mn}$ oxyhydroxide near the sediment/water interface was used first for labile $\mathrm{C}_{\text {org }}$ remineralization. This mobilizes $\mathrm{Mn}$ as $\mathrm{Mn}^{2+}$, which is then free to diffuse in pore-water solution. Residual labile $\mathrm{C}_{\text {org }}$, present at 

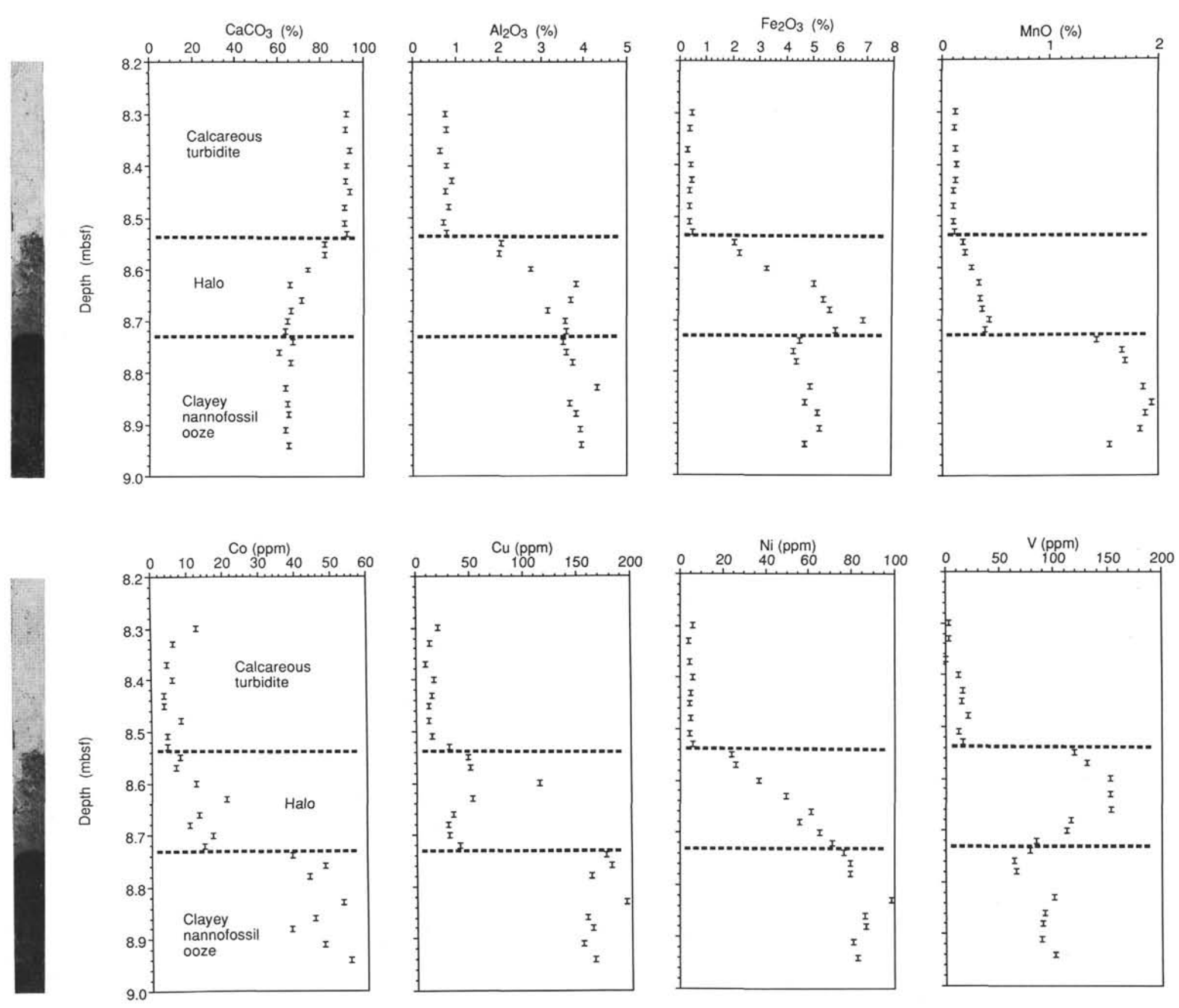

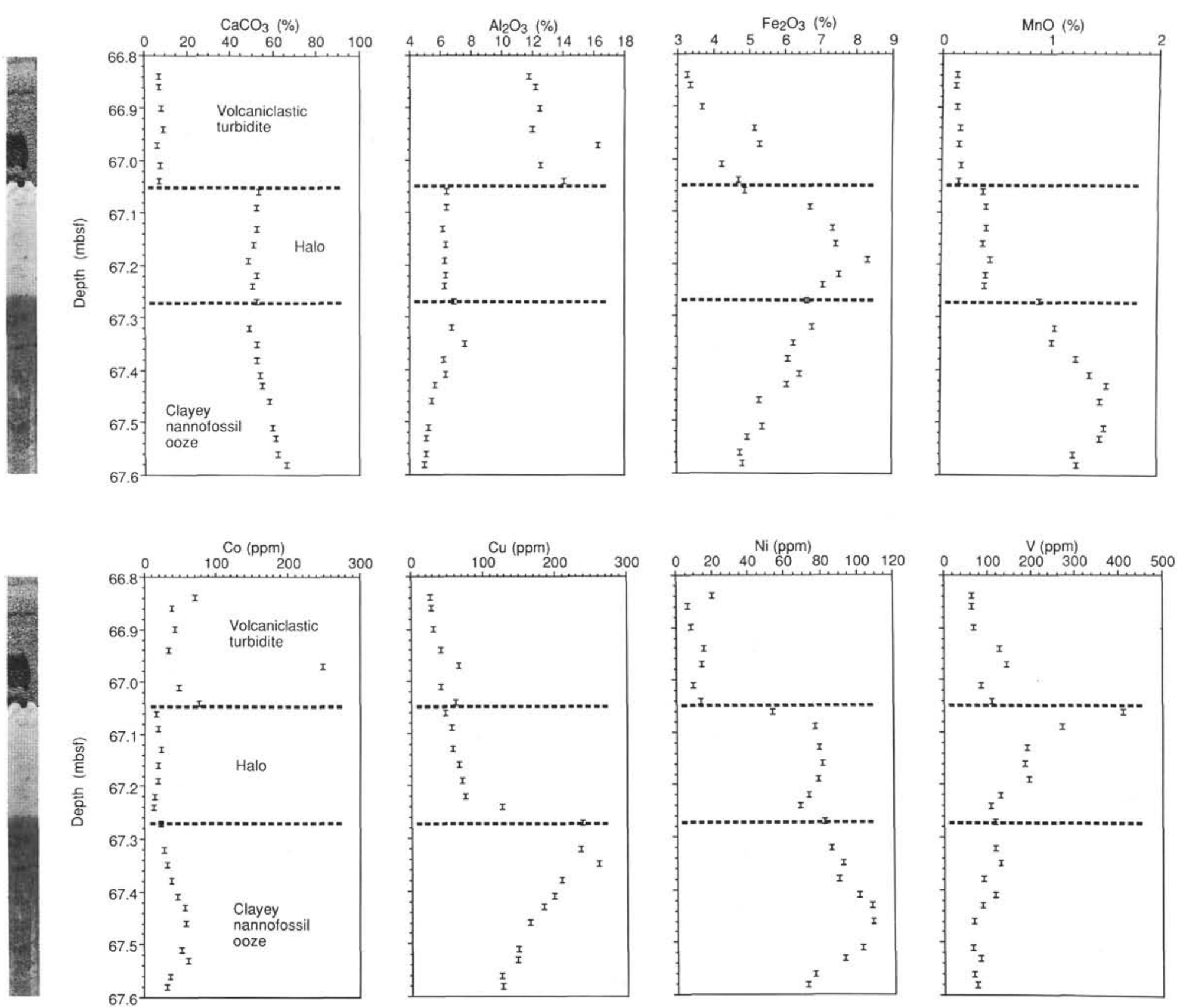

Figure 5. $\mathrm{CaCO}_{3}$ and geochemical profiles for $\mathrm{Al}_{2} \mathrm{O}_{3}, \mathrm{Fe}_{2} \mathrm{O}_{3}, \mathrm{MnO}, \mathrm{Co}, \mathrm{Cu}, \mathrm{Ni}$, and $\mathrm{V}$ through the base of the volcaniclastic turbidite, reduction halo, and underlying clayey nannofossil ooze in Section $135-837 \mathrm{~A}-8 \mathrm{H}-2$ (66.8-67.6 mbsf). 
Table 1. Results of geochemical analyses by ICP-AES through reduction halos in Section 135-834A-2H-1.

\begin{tabular}{|c|c|c|c|c|c|c|c|c|c|c|c|c|c|c|c|c|c|c|}
\hline \multirow[b]{2}{*}{$\begin{array}{l}\text { Core, section, } \\
\text { interval }(\mathrm{cm})\end{array}$} & \multirow[b]{2}{*}{$\begin{array}{l}\text { Depth } \\
\text { (mbsf) }\end{array}$} & \multicolumn{8}{|c|}{ Major elements } & \multicolumn{9}{|c|}{ Trace elements } \\
\hline & & $\begin{array}{c}\mathrm{CaCO}_{3} \\
\text { (\%) }\end{array}$ & $\begin{array}{l}\mathrm{Al}_{2} \mathrm{O}_{3} \\
(\%)\end{array}$ & $\begin{array}{l}\mathrm{Fe}_{2} \mathrm{O}_{3} \\
(\%)\end{array}$ & $\begin{array}{l}\mathrm{MnO} \\
(\%)\end{array}$ & $\begin{array}{l}\mathrm{MgO} \\
(\%)\end{array}$ & $\begin{array}{l}\mathrm{Na}_{2} \mathrm{O} \\
(\%)\end{array}$ & $\begin{array}{l}\mathrm{K}_{2} \mathrm{O} \\
(\%)\end{array}$ & $\begin{array}{l}\mathrm{TiO}_{2} \\
(\%)\end{array}$ & $\begin{array}{c}\text { Co } \\
(\mathrm{ppm})\end{array}$ & $\underset{(\mathrm{ppm})}{\mathrm{Cu}}$ & $\begin{array}{c}\mathrm{Ni} \\
(\mathrm{ppm})\end{array}$ & $\underset{(p p m)}{\mathrm{Sc}}$ & $\underset{(\mathrm{ppm})}{\mathrm{Sr}}$ & $\underset{(\mathrm{ppm})}{\mathrm{V}}$ & $\begin{array}{c}\mathrm{Y} \\
(\mathrm{ppm})\end{array}$ & $\underset{(\mathrm{ppm})}{\mathrm{Zn}}$ & $\begin{array}{l}\mathrm{P}_{2} \mathrm{O}_{5} \\
(\%)\end{array}$ \\
\hline \multicolumn{19}{|l|}{$135-834 \mathrm{~A}-$} \\
\hline $2 \mathrm{H}-1.70-71$ & 8.30 & 92.1 & 0.75 & 0.48 & 0.12 & 2.66 & 1.19 & 0.09 & 0.03 & 13 & 21 & 6 & 2 & 2727 & 3 & 7 & 35 & 0.15 \\
\hline $2 \mathrm{H}-1,73-74$ & 8.33 & 91.7 & 0.78 & 0.39 & 0.12 & 2.72 & 1.60 & 0.12 & 0.03 & 6 & 12 & 4 & 2 & 2600 & 3 & 7 & 21 & 0.16 \\
\hline $2 \mathrm{H}-1,77-78$ & 8.37 & 93.4 & 0.65 & 0.30 & 0.12 & 2.92 & 1.22 & 0.10 & 0.03 & 4 & 9 & 4 & 1 & 2565 & $<L D$ & 5 & 13 & 0.17 \\
\hline $2 \mathrm{H}-1,80-81$ & 8.40 & 92.3 & 0.79 & 0.44 & 0.13 & 2.74 & 1.43 & 0.12 & 0.04 & 6 & 17 & 6 & 2 & 2435 & 12 & 6 & 15 & 0.17 \\
\hline $2 \mathrm{H}-1.83-84$ & 8.43 & 91.8 & 0.91 & 0.46 & 0.12 & 2.90 & 1.20 & 0.10 & 0.04 & 3 & 15 & 5 & 2 & 2538 & 16 & 7 & 24 & 0.15 \\
\hline $2 \mathrm{H}-1.85-86$ & 8.45 & 93.4 & 0.77 & 0.41 & 0.11 & 2.97 & 1.17 & 0.08 & 0.04 & 4 & 12 & 5 & 2 & 2648 & 15 & 6 & 26 & 0.15 \\
\hline $2 \mathrm{H}-1.88-89$ & 8.48 & 91.4 & 0.84 & 0.41 & 0.11 & 2.76 & 1.24 & 0.08 & 0.04 & 8 & 12 & 5 & 2 & 2421 & 21 & 6 & 16 & 0.15 \\
\hline $2 \mathrm{H}-1.91-92$ & 8.51 & 90.9 & 0.73 & 0.38 & 0.11 & 2.70 & 1.19 & 0.09 & 0.03 & 5 & 15 & 5 & 2 & 2448 & 12 & 7 & 18 & 0.16 \\
\hline $2 \mathrm{H}-1.93-94$ & 8.53 & 92.0 & 0.79 & 0.51 & 0.11 & 2.70 & 1.17 & 0.07 & 0.04 & 4 & 30 & 6 & 2 & 2610 & 15 & 7 & 32 & 0.16 \\
\hline $2 \mathrm{H}-1.95-96$ & 8.55 & 81.9 & 2.07 & 2.07 & 0.20 & 2.26 & 1.82 & 0.23 & 0.10 & 8 & 48 & 24 & 5 & 2014 & 119 & 26 & 47 & 0.20 \\
\hline $2 \mathrm{H}-1.97-98$ & 8.57 & 81.6 & 2.02 & 2.29 & 0.21 & 2.02 & 1.87 & 0.23 & 0.09 & 7 & 50 & 26 & 6 & 2323 & 130 & 28 & 61 & 0.21 \\
\hline $2 \mathrm{H}-1.100-101$ & 8.60 & 74.1 & 2.77 & 3.29 & 0.27 & 1.73 & 2.21 & 0.31 & 0.13 & 12 & 115 & 37 & 8 & 1494 & 152 & 40 & 57 & 0.23 \\
\hline $2 \mathrm{H}-\mathrm{I} .103-104$ & 8.63 & 65.5 & 3.82 & 5.09 & 0.34 & 1.43 & 2.65 & 0.44 & 0.17 & 21 & 52 & 50 & 10 & 1085 & 152 & 49 & 76 & 0.27 \\
\hline $2 \mathrm{H}-1.106-107$ & 8.66 & 71.0 & 3.68 & 5.43 & 0.35 & 1.27 & 3,08 & 0.52 & 0.15 & 13 & 35 & 61 & 9 & 1133 & 153 & 50 & 76 & 0.30 \\
\hline $2 \mathrm{H}-1,108-109$ & 8.68 & 66.0 & 3.15 & 5.66 & 0.37 & 1.30 & 2.46 & 0.43 & 0.14 & 10 & 29 & 56 & 9 & 1076 & 116 & 54 & 84 & 0.28 \\
\hline $2 \mathrm{H}-1.110-111$ & 8.70 & 64.5 & 3.58 & 6.92 & 0.44 & 1.45 & 2.51 & 0.46 & 0.17 & 17 & 31 & 65 & 10 & 1109 & 112 & 61 & 101 & 0.32 \\
\hline $2 \mathrm{H}-1,112-113$ & 8.72 & 63.7 & $3.61^{\circ}$ & 5.92 & 0.40 & 1.16 & 3.41 & 0.49 & 0.15 & 15 & 41 & 71 & 8 & 1037 & 84 & 53 & 92 & 0.32 \\
\hline $2 \mathrm{H}-1.114-115$ & 8.74 & 67.1 & 3.52 & 4.57 & 1.44 & 1.14 & 2.67 & 0.33 & 0.16 & 39 & 177 & 76 & 10 & 1305 & 78 & 62 & 84 & 0.33 \\
\hline $2 \mathrm{H}-1.116-117$ & 8.76 & 60.6 & 3.60 & 4.34 & 1.67 & 1.08 & 2.67 & 0.34 & 0.16 & 48 & 181 & 79 & 9 & 1133 & 63 & 62 & 77 & 0.33 \\
\hline $2 \mathrm{H}-1,118-119$ & 8.78 & 65.8 & 3.75 & 4.47 & 1.70 & 1.14 & 2.70 & 0.34 & 0.17 & 44 & 163 & 80 & 10 & 1164 & 65 & 66 & 82 & 0.34 \\
\hline $2 \mathrm{H}-1.123-124$ & 8.83 & 63.4 & 4.31 & 4.96 & 1.87 & 1.11 & 3.48 & 0.42 & 0.19 & 53 & 195 & 98 & 10 & 1086 & 101 & 62 & 89 & 0.38 \\
\hline $2 \mathrm{H}-1.126-127$ & 8.86 & 64.5 & 3.67 & 4.76 & 1.94 & 1.13 & 2.66 & 0.32 & 0.17 & 45 & 159 & 86 & 10 & 1279 & 92 & 69 & 87 & 0.35 \\
\hline $2 \mathrm{H}-1,128-129$ & 8.88 & 64.8 & 3.82 & 5.23 & 1.88 & 1.23 & 2.75 & 0.35 & 0.17 & 39 & 164 & 87 & 10 & 1154 & 90 & 70 & 114 & 0.37 \\
\hline $2 \mathrm{H}-1,131-132$ & 8.91 & 63.8 & 3.91 & 5.32 & 1.84 & 1.28 & 2.58 & 0.33 & 0.19 & 48 & 155 & 81 & 11 & 1137 & 89 & 69 & 95 & 0.37 \\
\hline $2 \mathrm{H}-1.134-135$ & 8.94 & 64.9 & 3.95 & 4.76 & 1.55 & 1.14 & 3.13 & 0.35 & 0.17 & 55 & 166 & 83 & 10 & 1106 & 102 & 62 & 90 & 0.37 \\
\hline
\end{tabular}

Note: $\angle \mathrm{LD}=$ less than limits of detection.
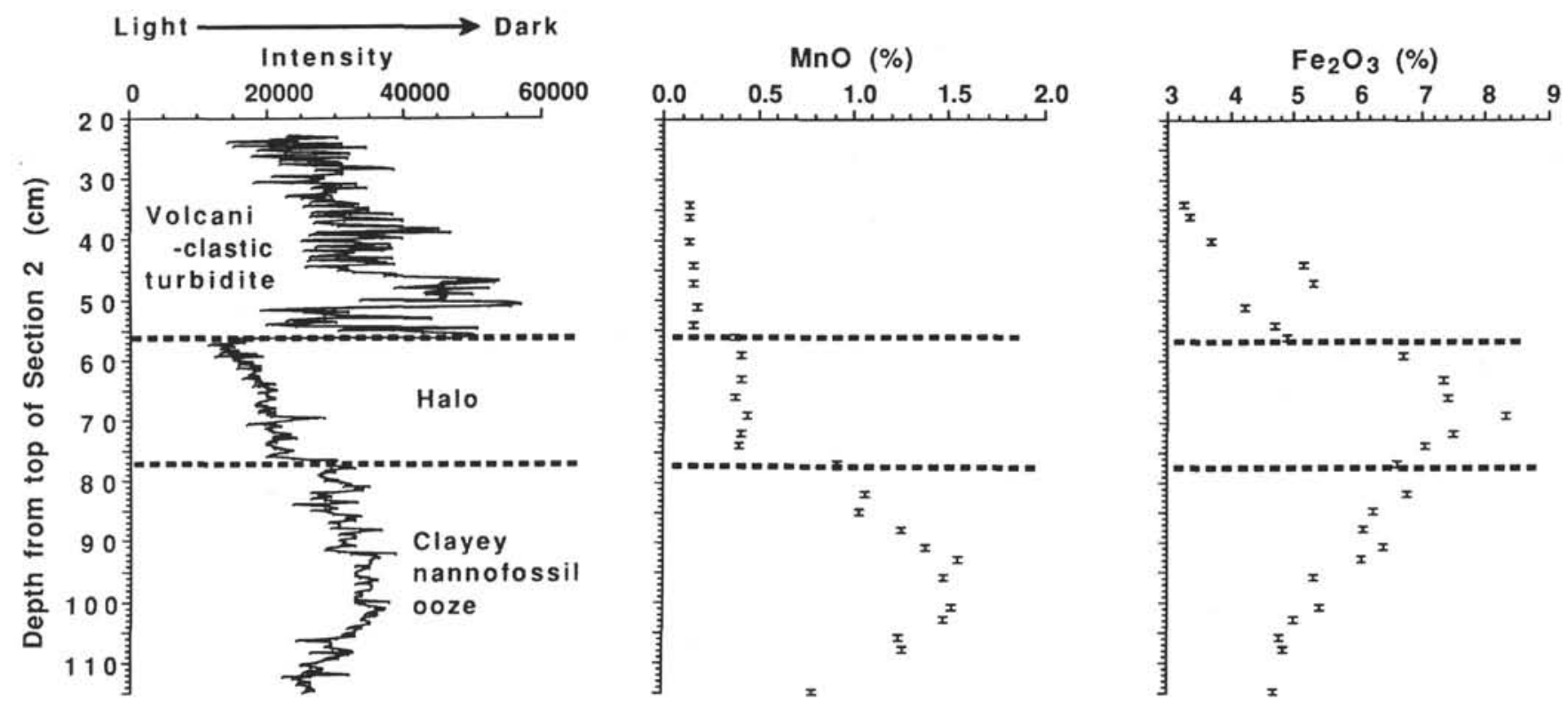

Figure 6. Quantitative color log through the interval $135-837 \mathrm{~A}-8 \mathrm{H}-2(20-115 \mathrm{~cm})$ showing variation in intensity in the red video primary $(700 \mathrm{~nm})$, made using the CIE LAB color system, with $\mathrm{MnO}$ and $\mathrm{Fe}_{2} \mathrm{O}_{3}$ profiles plotted alongside. Note that changes in $\mathrm{Mn}$ concentration broadly correlate with variations in color intensity in the halo and underlying clayey nannofossil ooze, with low manganese values correlating with lighter color and high manganese values correlating with darker color. Variations in Fe content appear to be unrelated to variations in color, except in the base of the turbidite where a short interval of darker color correlates with increased Fe content.

the top of the buried former sediment surface, was then further remineralized by $\mathrm{Fe}$ oxyhydroxide reduction. This accounts for the low Fe levels observed immediately below the turbidites.

The final step of the model is that $\mathrm{Fe}^{2+}$ downward diffusion and reaction with Mn (IV) oxyhydroxide (Postma, 1985), mobilized further $\mathrm{Mn}^{2+}$ in the lower parts of the haloes. This exchange of solid phase $\mathrm{Mn}$ by $\mathrm{Fe}$ is the reason for the $\mathrm{Fe}$ maxima observed within the reduction halo and is the cause of the sharp color change at the base of the halo. This color alteration of the haloes is ascribed to the lack of Mn oxyhydroxide because, although the Fe level fluctuates through the haloes, this does not appear to affect their color (Fig. 6). From the $\mathrm{Fe}$ and $\mathrm{Mn}$ profiles of the Nares Abyssal Plain haloes, it was possible to reconstruct profiles of the labile $\mathrm{C}_{\mathrm{org}}$ at the buried sediment surface because of the homogeneity of the sediments. These profiles were of a reasonable magnitude and shape in comparison with modern surface sediments in that area. In the present cases, compositional fluctuations 
Table 2. Results of geochemical analyses by ICP-AES through reduction halos in Section 135-837A-8H-2.

\begin{tabular}{|c|c|c|c|c|c|c|c|c|c|c|c|c|c|c|c|c|c|c|}
\hline \multirow[b]{2}{*}{$\begin{array}{l}\text { Core, section. } \\
\text { interval }(\mathrm{cm})\end{array}$} & \multirow[b]{2}{*}{$\begin{array}{l}\text { Depth } \\
\text { (mbsf) }\end{array}$} & \multicolumn{8}{|c|}{ Major elements } & \multicolumn{9}{|c|}{ Trace elements } \\
\hline & & $\begin{array}{c}\mathrm{CaCO}_{3} \\
(\%)\end{array}$ & $\begin{array}{l}\mathrm{Al}_{2} \mathrm{O}_{3} \\
(\%)\end{array}$ & $\begin{array}{l}\mathrm{Fe}_{2} \mathrm{O}_{3} \\
(\%)\end{array}$ & $\begin{array}{l}\mathrm{MnO} \\
(\%)\end{array}$ & $\begin{array}{l}\mathrm{MgO} \\
(\%)\end{array}$ & $\begin{array}{l}\mathrm{Na}_{2} \mathrm{O} \\
(\%)\end{array}$ & $\begin{array}{l}\mathrm{K}_{2} \mathrm{O} \\
(\%)\end{array}$ & $\begin{array}{l}\mathrm{TiO}_{2} \\
(\%)\end{array}$ & $\begin{array}{c}\text { Co } \\
(\mathrm{ppm})\end{array}$ & $\underset{(\mathrm{ppm})}{\mathrm{Cu}}$ & $\begin{array}{c}\mathrm{Ni} \\
(\mathrm{ppm})\end{array}$ & $\begin{array}{c}\mathrm{Sc} \\
(\mathrm{ppm})\end{array}$ & $\begin{array}{c}\mathrm{Sr} \\
(\mathrm{ppm})\end{array}$ & $\begin{array}{c}\mathrm{V} \\
(\mathrm{ppm})\end{array}$ & $\begin{array}{c}\mathrm{Y} \\
\text { (ppm) }\end{array}$ & $\underset{(\mathrm{ppm})}{\mathrm{Zn}}$ & $\begin{array}{l}\mathrm{P}_{2} \mathrm{O}_{5} \\
(\%)\end{array}$ \\
\hline \multicolumn{19}{|l|}{$135-837 \mathrm{~A}$. } \\
\hline $8 \mathrm{H}-2,34-35$ & 66.84 & 6.8 & 11.79 & 3,25 & 0.14 & 1.43 & 5.04 & 1.20 & 0.53 & 70 & 27 & 20 & 16 & 174 & 64 & 46 & 74 & 0.12 \\
\hline $8 \mathrm{H}-2,36-37$ & 66.86 & 6.7 & 12.20 & 3.35 & 0.13 & 1.48 & 4.85 & 1.15 & 0.52 & 38 & 28 & 6 & 16 & 187 & 65 & 41 & 75 & 0.14 \\
\hline $8 \mathrm{H}-2,40-41$ & 66.90 & 7.9 & 12.47 & 3.69 & 0.14 & 1.72 & 4.58 & 1.05 & 0.55 & 42 & 31 & 8 & 17 & 202 & 69 & 40 & 72 & 0.14 \\
\hline $8 \mathrm{H} \cdot 2,44-45$ & 66.94 & 8.9 & 11.97 & 5.16 & 0.16 & 2.12 & 4.16 & 1.04 & 0.61 & 34 & 41 & 15 & 19 & 197 & 126 & 39 & 77 & 0.15 \\
\hline $8 \mathrm{H}-2,47-48$ & 66.97 & 6.0 & 16.24 & 5.31 & 0.16 & 2.58 & 4.89 & 0.95 & 0.70 & 248 & 66 & 14 & 23 & 205 & 143 & 33 & 86 & 0.19 \\
\hline $8 \mathrm{H} \cdot 2,51-52$ & 67.01 & 7.3 & 12.56 & 4.23 & 0.18 & 1.96 & 4.27 & 1.00 & 0.59 & 49 & 42 & 9 & 19 & 189 & 85 & 37 & 77 & 0.15 \\
\hline $8 \mathrm{H}-2,54-55$ & 67.04 & 7.1 & 14.07 & 4.71 & 0.16 & 2.36 & 4.09 & 0.86 & 0.62 & 76 & 61 & 14 & 22 & 205 & 109 & 34 & 77 & 0.16 \\
\hline $8 \mathrm{H}-2.56-57$ & 67.06 & 53.2 & 6.42 & 4.90 & 0.38 & 2.12 & 3.05 & 0.66 & 0.35 & 16 & 47 & 53 & 17 & 828 & 411 & 51 & 88 & 0.28 \\
\hline $8 \mathrm{H}-2,59-60$ & 67.09 & 52.0 & 6.43 & 6.72 & 0.41 & 2.28 & 2.97 & 0.69 & 0.34 & 20 & 56 & 77 & 17 & 853 & 270 & 52 & 112 & 0.32 \\
\hline $8 \mathrm{H}-2,63-64$ & 67.13 & 52.0 & 6.12 & 7.26 & 0.41 & 2.35 & 2.75 & 0.70 & 0.34 & 24 & 57 & 79 & 16 & 846 & 190 & 52 & 109 & 0.33 \\
\hline $8 \mathrm{H}-2,66-67$ & 67.16 & 50.7 & 6.36 & 7.43 & 0.38 & 2.23 & 3.18 & 0.77 & 0.33 & 19 & 66 & 81 & 16 & 817 & 185 & 49 & 112 & 0.35 \\
\hline $8 \mathrm{H}-2.69-70$ & 67.19 & 48.1 & 6.29 & 8.33 & 0.45 & 2.49 & 2.82 & 0.70 & 0.36 & 19 & 71 & 79 & 18 & 1010 & 195 & 57 & 128 & 0.37 \\
\hline $8 \mathrm{H}-2.72-73$ & 67.22 & 52.4 & 6.37 & 7.52 & 0.41 & 2.18 & 3.03 & 0.71 & 0.35 & 15 & 75 & 73 & 17 & 884 & 130 & 53 & 117 & 0.36 \\
\hline $8 \mathrm{H}-2.64-75$ & 67.24 & 50.0 & 6.30 & 7.08 & 0.41 & 2.07 & 2.97 & 0.67 & 0.35 & 14 & 127 & 69 & 16 & 842 & 107 & 50 & 122 & 0.35 \\
\hline $8 \mathrm{H}-2.77-78$ & 67.27 & 52.1 & 6.87 & 6.64 & 0.91 & 2.15 & 3.23 & 0.66 & 0.37 & 24 & 238 & 82 & 18 & 929 & 117 & 55 & 120 & 0.38 \\
\hline $8 \mathrm{H} \cdot 2,82-83$ & 67.32 & 48.8 & 6.79 & 6.78 & 1.06 & 2.23 & 3.11 & 0.66 & 0.38 & 29 & 236 & 86 & 17 & 879 & 118 & 51 & 134 & 0.37 \\
\hline $8 \mathrm{H}-2,85-86$ & 67.35 & 52.4 & 7.57 & 6.25 & 1.03 & 1.98 & 3.97 & 0.76 & 0.38 & 32 & 261 & 92 & 16 & 917 & 130 & 53 & 113 & 0.39 \\
\hline $8 \mathrm{H}-2,88-89$ & 67.38 & 52.1 & 6.23 & 6.10 & 1.25 & 2.07 & 2.93 & 0.66 & 0.35 & 38 & 208 & 90 & 16 & 912 & 91 & 54 & 105 & 0.36 \\
\hline $8 \mathrm{H}-2,91-92$ & 67.41 & 53.8 & 6.35 & 6.42 & 1.38 & 2.27 & 2.91 & 0.79 & 0.35 & 47 & 198 & 101 & 17 & 1076 & 117 & 57 & 108 & 0.38 \\
\hline $8 \mathrm{H}-2,93-94$ & 67.43 & 54.5 & 5.62 & 6.06 & 1.54 & 2.15 & 2.60 & 0.72 & 0.33 & 57 & 183 & 108 & 16 & 961 & 87 & 55 & 102 & 0.37 \\
\hline $8 \mathrm{H}-2,96-97$ & 67.46 & 58.0 & 5.43 & 5.31 & 1.48 & 1.96 & 2.80 & 0.75 & 0.29 & 58 & 165 & 108 & 14 & 965 & 69 & 50 & 97 & 0.36 \\
\hline $8 \mathrm{H}-2,101-102$ & 67.51 & 59.8 & 5.26 & 5.39 & 1.51 & 2.04 & 2.59 & 0.67 & 0.30 & 53 & 148 & 102 & 15 & 1014 & 67 & 50 & 95 & 0.37 \\
\hline $8 \mathrm{H}-2,103-104$ & 67.53 & 61.1 & 5.12 & 4.98 & 1.48 & 1.84 & 2.80 & 0.69 & 0.29 & 61 & 147 & 93 & 13 & 957 & 83 & 43 & 92 & 0.38 \\
\hline $8 \mathrm{H}-2,106-107$ & 67.56 & 62.3 & 5.10 & 4.78 & 1.24 & 1.82 & 2.51 & 0.55 & 0.29 & 37 & 126 & 76 & 14 & 982 & 69 & 43 & 81 & 0.35 \\
\hline $8 \mathrm{H}-2,108-109$ & 67.58 & 66.2 & 4.94 & 4.83 & 1.26 & 1.85 & 2,44 & 0.45 & 0.29 & 33 & 127 & 72 & 15 & 1007 & 75 & 44 & 90 & 0.34 \\
\hline \multicolumn{2}{|l|}{ USGS BHVO-I } & & 13.85 & 11.24 & 0.17 & 6.36 & 1.80 & 0.56 & 2.75 & 48 & 135 & 118 & 34 & 285 & 303 & 28 & 117 & 0.33 \\
\hline \multicolumn{2}{|c|}{ "Recommended" value } & & 13.80 & 12.23 & 0.168 & 7.23 & 2.26 & 0.52 & 2.71 & 45 & 136 & 121 & 31.8 & 403 & 317 & 27.6 & 105 & 0.27 \\
\hline
\end{tabular}

Note: "Recommended" value taken from Govindaraju (1989).

make it difficult to estimate the initial levels of $\mathrm{Mn}$ and Fe that are necessary to perform a reconstruction of $\mathrm{C}_{\mathrm{org}}$ profiles. From the profile shapes, however, it is likely that $>0.5 \% \mathrm{MnO}$ has been mobilized throughout the haloes, and that the $\mathrm{Fe}$ maxima represent an additional $2 \% \mathrm{Fe}_{2} \mathrm{O}_{3}$ added by $\mathrm{Fe}^{3+}$ precipitation from $\mathrm{Fe}^{2+}$.

A major contrast between the Mn profiles observed immediately above and below the haloes in the Leg 135 examples and those from the Nares Abyssal Plain arises because of the different thicknesses of the overlying turbidites. The $\mathrm{Mn}^{2+}$ remobilized to pore-water solution will tend to diffuse upward and downward out of the halo regions, with the relative fluxes partitioned according to the gradients in porewater $\mathrm{Mn}^{2+}$ concentration. Much of the Mn remobilized from the haloes in the Nares cases was relocated into the lower reaches of the turbidites, where it was evident as dark laminae. This was caused by reprecipitation of $\mathrm{Mn}^{2+}$ by bottom-water oxygen diffusing downward through the short (decimeter thick) turbidites investigated there. In the Lau Basin examples, thick turbidites were selected for investigation, so that oxidation of the turbidite surface was occurring $3.5-5 \mathrm{~m}$ above the haloes. These distances are so long that only small upward fluxes of $\mathrm{Mn}^{2+}$ could have been involved before oxic conditions were encountered (concentration gradient $\delta \mathrm{c} / \delta x$ small for $\mathrm{Mn}^{2+}$ in solution because $x$ is large). Therefore, no Mn enrichments were observed in the lower reaches of the Lau Basin turbidites, and larger enrichments of $\mathrm{Mn}$ are found just below the haloes in both cases $(1.5 \%-2 \% \mathrm{MnO})$ than in the Nares cases $(<0.4 \% \mathrm{MnO})$. The mechanism of removal of $\mathrm{Mn}^{2+}$ from solution to the solid phase in the downward direction, which is necessary to provide a sink to establish a pore-water $\mathrm{Mn}^{2+}$ gradient, is not certain. The sink may be absorption of $\mathrm{Mn}^{2+}$ by pre-existing Mn oxyhydroxide, which is an effective scavenger for many cations (Means et al., 1978; Kadko et al., 1987).

\section{Congener Elements}

In slowly accumulated sediments, a number of elements are found enriched along with $\mathrm{Mn}$ oxides and oxyhydroxides. The elements most regularly identified are $\mathrm{Co}, \mathrm{Cu}$, and $\mathrm{Ni}$ (Krishnaswami, 1976; Li, 1981; Thomson et al., 1984; Kadko, 1985; Piper, 1988). Several other elements (e.g., Ce, Mo, Sb, V, and $\mathrm{Zn}$ ) are likely to be similarly enriched in this hydrogenous or authigenic fraction, but either the enrichment is less marked or the element is less frequently measured (Piper et al., 1987; Thomson et al., 1984, 1989). Hodkinson et al. (1986) have shown that the sediments of the Lau Basin contain a hydrothermal component that is enriched in $\mathrm{Mn}, \mathrm{Cu}, \mathrm{Zn}, \mathrm{Pb}$, and $\mathrm{P}$ and to a lesser extent $\mathrm{Fe}, \mathrm{Co}$, and V.

It might be expected a priori that when the Mn and Fe oxyhydroxides originally present in the solid phase of the halo regions are reduced to the solution phase after turbidite emplacement, then the congener elements will be similarly mobilized. This was observed in the Nares cases and is also evident in the Lau Basin reduction haloes. Thus, $\mathrm{Co}$ and $\mathrm{Cu}$ are generally at low values in the haloes in comparison with the underlying pelagic sediments, consistent with a downward movement similar to that of Mn (Figs. 4-5), although a local peak in $\mathrm{Cu}$ occurs within the halo in Section 135-834A-2H-1. Nickel also has generally lower values in the haloes, but the lowest values are just under the former sediment surface and a marked gradient in $\mathrm{Ni}$ content with depth is present in the halo in Section 135-834A-2H1. None of these three elements have exactly the same shape of profile as $\mathrm{Mn}$, demonstrating that the individual elements have characteristic responses to the diagenesis responsible for halo formation. Cobalt, $\mathrm{Cu}$, and $\mathrm{Ni}$ were similarly found to be depleted in the Nares examples, but in those cases clear evidence also existed of immobilization at the base of the turbidites along with $\mathrm{Mn}$, which is not seen here for the reasons already discussed.

The behavior of $\mathrm{V}$ (which was not measured in the Nares examples) is distinctive in that it is enriched in the solid phase in both haloes. Downhole bulk geochemistry data for all the backarc sites show that highest vanadium contents (up to $1200 \mathrm{ppm}$ ) nearly always occur within reduction haloes (R.A. Hodkinson, pers. comm., 1992). This implies that, in contrast to the other elements discussed, a mobile $\mathrm{V}$ fraction has migrated into, rather than out of, the haloes and has 
been immobilized there. Vanadium can have an appreciably enhanced concentration in marine pore waters compared with seawater (Emerson and Huested, 1991), and does undergo valency changes at near zero $\mathrm{E}_{\mathrm{h}}$ and near neutral $\mathrm{pH}$ values (Lewan, 1984; Breit and Wanty, 1991). A close relationship between $\mathrm{V}$ and $\mathrm{Fe}$ has been demonstrated in hydrothermal precipitates and sediments (Trefry and Metz, 1989). From comparison of the $\mathrm{V}$ and Fe profile shapes (Figs. 4-5), however, it appears that $\mathrm{V}$ is behaving differently from $\mathrm{Fe}$ within the haloes because the profile shapes are different and the maximum $\mathrm{V}$ values do not coincide with those for $\mathrm{Fe}$.

On this interpretation, the haloes are hemipelagic sediments whose appearance has been altered as a consequence of metal migration following reduction. Support for this contention is seen in the isocon diagrams (Fig. 7), made by plotting the average elemental concentrations in the haloes vs. the average elemental concentrations in the underlying sediments (Grant, 1986). Although the geochemically inert elements lie close to the isocon equiline, the redox-sensitive elements $\mathrm{Mn}, \mathrm{Co}$, and $\mathrm{Cu}$ are clearly depleted in the haloes and are $\mathrm{V}$ enriched (Fig. 7). The apparent $\mathrm{Ca}, \mathrm{Sr}$, and $\mathrm{Mg}$ enrichment in the halo of Section $135-834 \mathrm{~A}-2 \mathrm{H}-1$ is a result of the greater carbonate content of the halo (Fig. 4),

\section{Persistence of Reduction Haloes}

The haloes have been ascribed to the local absence of Mn oxyhydroxide in the sediments. Deeply buried sediments are often anoxic, so that $\mathrm{Mn}$ oxides and hydroxides have been reduced, $\mathrm{Mn}^{2+}$ has diffused upward and little Mn persists in the anoxic deep sediments. This is clearly not the case in these cores, where high levels of solid-phase Mn are still found at depth (e.g., at $67 \mathrm{~m}$ depth in Section 135-837A-8H-2; Fig. 5). Recent accumulation rates of sediments in the Lau Basin are variable (Cronan et al., 1986), but Reich (1990) has estimated an average rate around $1.5 \mathrm{~cm} \mathrm{k.y.}{ }^{-1}$ over the past 900 k.y.; and Rothwell et al. (this volume) deduce a similar average hemipelagic rate over the last $3 \mathrm{~m} . \mathrm{y}$. at Sites 834 and 835 . At low pelagic rates of sediment accumulation, most $\mathrm{C}_{\text {org }}$ remineralization occurs by oxic degradation, so that only refractory $\mathrm{C}_{\text {org }}$ persists at depths greater than several centimeters or a few decimeters (Rabouille and Gaillard, 1991). All available $\mathrm{C}_{\text {org }}$ analyses in Hole $837 \mathrm{~A}$ cores are very low (average of eight finite values in ten determinations: $0.12 \%$, range $0.01 \%-0.2 \%$; Parson, Hawkins, Allan, et al., 1992, p. 319). Porewater data also show clearly that buried $\mathrm{C}_{\text {org }}$ remineralization is driving very little sulfate reduction, because $\mathrm{SO}_{4}^{2-}$ was observed to be close to the seawater value and $\mathrm{NH}_{4}^{+}$is at low levels, respectively, at all depths (Parson, Hawkins, Allan, et al., 1992, p. 320). Decreasing $\mathrm{SO}_{4}^{2-}$ and increasing $\mathrm{NH}_{4}^{+}$levels are found with increasing depth in sediments where sulfate reduction and sulfide production are active. It is inferred from these data, therefore, that the geochemical environment of the Lau Basin cores is post-oxic rather than sulfidic (Berner, 1981), although the critical parameters to demonstrate this unequivocally are not available. This implies that the persistence of Mn oxyhydroxides is a consequence of the low levels of refractory buried $\mathrm{C}_{\mathrm{org}}$. The $\mathrm{Mn}^{2+}$ levels observed in pore-water solution (Parson, Hawkins, Allan, et al., 1992, p. 320) are likely to be controlled by an equilibrium uptake onto $\mathrm{CaCO}_{3}$ surfaces to form $(\mathrm{Mn}, \mathrm{Ca}) \mathrm{CO}_{3}$ (Middleburg et al., 1987).

\section{Implications for Visual Core Interpretation}

The above mechanism of the formation of reduction haloes leads to some generalizations that may be useful in sedimentologic interpretations of fine-scale depositional history:

1. A halo is unlikely to form if turbidite emplacement is erosive, so that it removes the near-surface layer. This is generally the most fluid part of the sediment (i.e., it has the highest water content) and contains the highest levels of reactive $\mathrm{C}_{\text {org }}$ to drive the reduction process.

2. Conversely, the presence of a halo implies that emplacement of the overlying turbidite did not erode the pre-existing sediment surface to a marked extent.

3. The thickness of the halo under thick turbidites (meters in thickness) represents the profile of labile $\mathrm{C}_{\mathrm{org}}$ of the buried surface. If the turbidite is thin (a few decimeters in thickness), then the halo development may have been terminated before completion by the breakthrough of bottom-water oxygen by downward diffusion. In such cases, a diagenetic enrichment of Mn oxyhydroxides can be formed in the lower reaches of the turbidite.
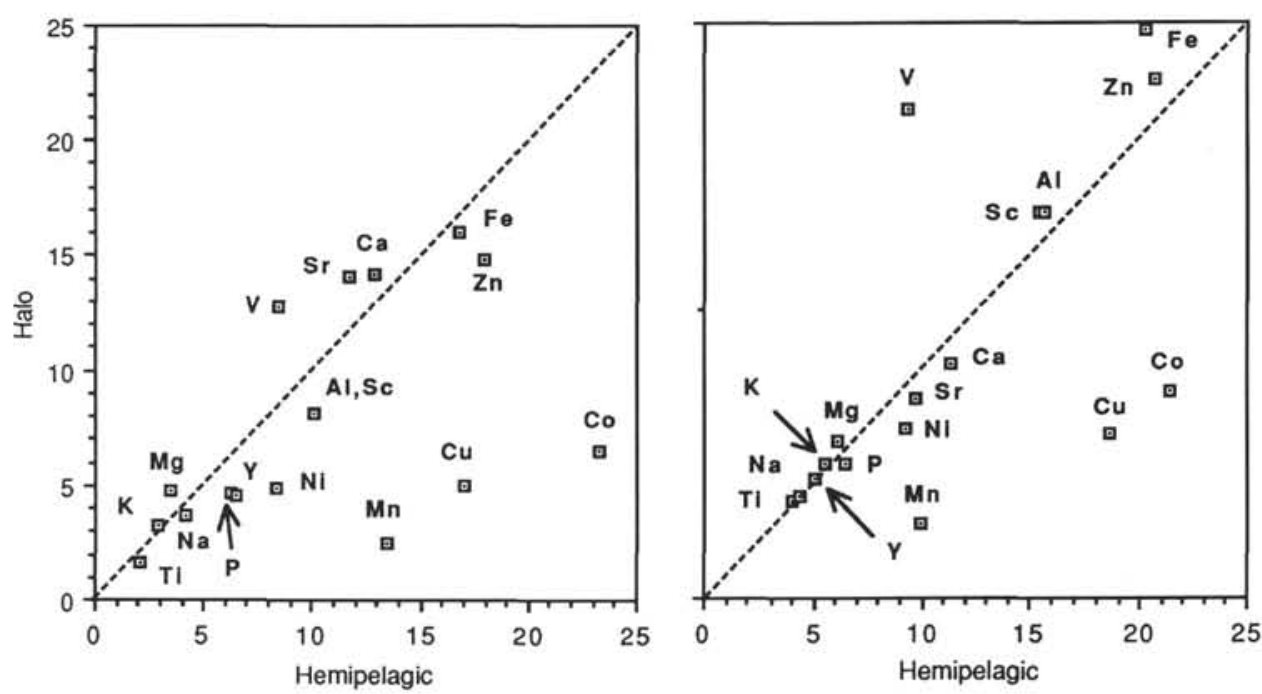

Figure 7. Isocon diagrams (Grant, 1986) for Sections 135-834A-2H-1 (left) and 135-837A-8H-2 (right). In this diagram, the average elemental concentration value in the halo section is plotted vs. the average elemental concentration value in the underlying sediments. Arbitrary factors have been selected to bring all elements on to the same scale as follows: $0.01=\mathrm{Sr} ; 0.1=\mathrm{Cu}, \mathrm{Ni}, \mathrm{V}$, and $\mathrm{Y} ; 0.2=\mathrm{Zn} ; 0.5=\mathrm{Ca}$ and $\mathrm{Co} ; 2=\mathrm{Na} ; 5=\mathrm{Al}, \mathrm{Mg}$, and Fe; 10 $=\mathrm{Mn}$ and $\mathrm{K} ; 20=\mathrm{Ti} ;$ and $40=\mathrm{P}$. 
4. It is the absence of Mn oxyhydroxides that causes the light color of haloes, rather than any variation in Fe content. It has been stated that the red/brown color of the Lau Basin carbonate sediments is caused by the presence of amorphous $\mathrm{Fe}$ and $\mathrm{Mn}$ oxides and oxyhydroxides (Moorby et al., 1986; Reich, 1990; Reich et al., 1990); the sections investigated here make it likely that $\mathrm{Mn}$ is the dominant control on brown coloration (Fig. 6).

The development of reduction haloes beneath turbidites is generally uncommon at all the backarc sites, with the exception of Sites 837 and 839 , where $30 \%-40 \%$ of turbidite events show the development of reduction haloes. Sites 837 and 839 contain both the greatest number and thickest haloes (Figs. 8-9). Both these sites were drilled on basin floors, within $70 \mathrm{~km}$ of the axial rift zone of the East Lau Spreading Center, and show a similar sequence of thick, vitric silt and sand turbidites interbedded with hemipelagic clayey nannofossil oozes and mixed sediments.

Reduction haloes are rarely developed at Sites 834 and 835 , with under $10 \%$ of turbidites showing haloes. Of all the Lau Basin backarc sites, reduction haloes are the least common at Site 835 , where redeposited sediments comprise $66 \%$ of the sediment column above basement. These allochthonous sediments comprise thick, muddy, debris-flow deposits; coherent rafted blocks; and thick, mud turbidites derived from catastrophic failure around the basin margins (Rothwell et al., this volume). The basin flanks surrounding the basin in which Site 835 was drilled are exceptionally steep (up to $30^{\circ}$ ), and stratigraphic evidence is present for erosive emplacement of at least some of the sediment gravity-flow deposits (Rothwell et al., this volume). This may account for the rarity of reduction haloes at this site. Equal numbers of haloes occur at Sites 836 and 835, although the former sediment column above basement is only $13 \%$ of the thickness at Site 835 .

Site 838 was drilled on the sediment covered, lower flank of a basement high. The allochthonous sediments here are generally much coarser grained than those drilled at Sites 837 and 839, and are dominated by coarse disorganized vitric gravels (probably deposited by cohesive debris flows) and coarse-grained, structureless volcanic sands (probably deposited by high concentration turbidity currents).

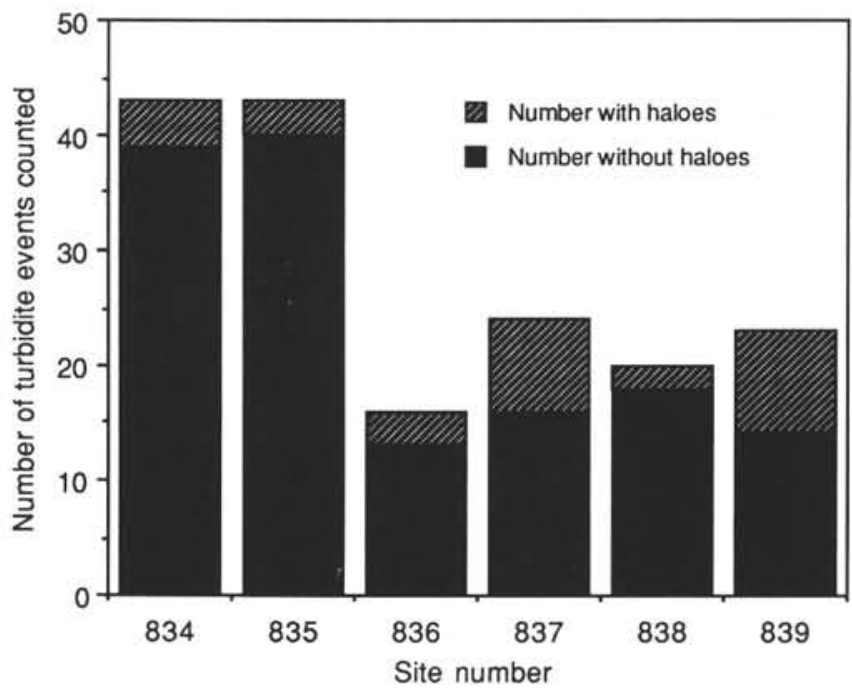

Figure 8. Histogram showing the number of turbidite events present at each Leg 135 backarc site with and without underlying haloes. Turbidites showing the development of a reduction halo are a minority case. Note that a turbidite event is defined as either a single turbidite interbedded in hemipelagic clayey nannofossil ooze or mixed sediment or as a discrete "package" of stacked turbidites interbedded with hemipelagic deposits.

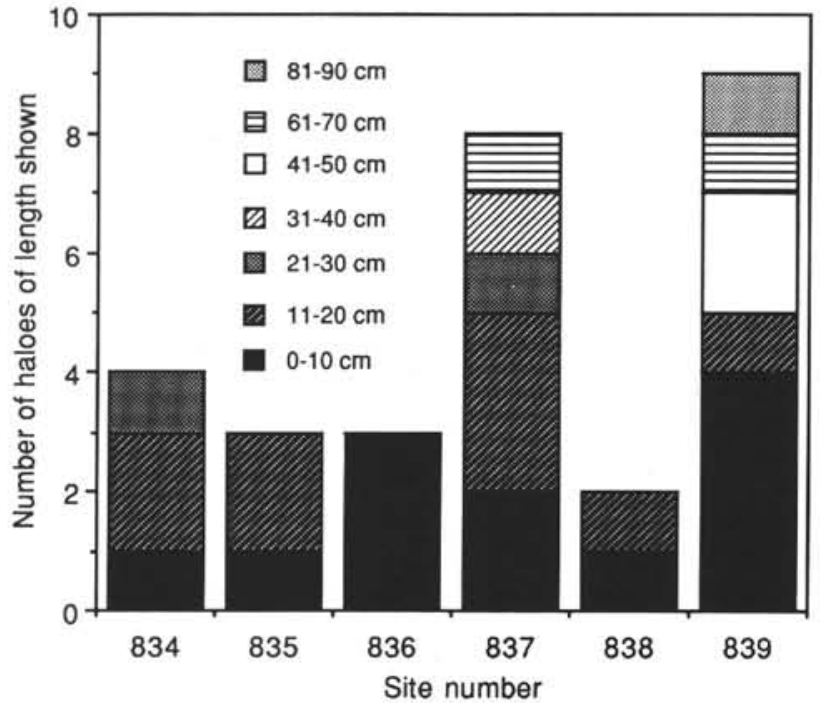

Figure 9. Histogram showing the distribution of halo thickness at each Leg 135 backarc site. Note the occurrence of longer haloes at Sites 837 and 839 (see discussion in text).

The redeposited sediments drilled at Site 838 are generally the coarsest grained of those drilled at all the backarc sites. The paucity of reduction haloes at Site 838 may reflect the greater potential for erosion of underlying deposits provided by such coarse-grained sediment gravity flows on the relatively steep local slopes.

The largest concentrations of in-situ labile $\mathrm{C}_{\text {org }}$ necessary to fuel the formation of the reduction haloes are expected to be present in the uppermost few decimeters of the sediment (Grundmanis and Murray, 1982; Thomson et al., 1989); indeed, 26 out of the 29 haloes identified under 169 turbidite events at six backarc sites are $<50 \mathrm{~cm}$ in length (Fig. 9). Three haloes are longer than this, two of which are shown in Figure 10, and these merit further consideration. In certain modern oxic sediments, detailed $\mathrm{C}_{\text {org }}$ profiles have been determined where the amount of labile $\mathrm{C}_{\text {org }}$ declines quasi-exponentially with depth down to $100 \mathrm{~cm}$ (Muller and Mangini, 1980). In slowly accumulated sediments, the depth over which labile $\mathrm{C}_{\text {org }}$ is consumed is a function of several parameters, including bottom-water $\mathrm{O}_{2}$ concentration, the fluxes of $\mathrm{C}$ and total sediment, and the rate constant of labile $\mathrm{C}_{\text {org }}$ oxidation (Rabouille and Gaillard, 1991). Modern models visualize that labile $\mathrm{C}_{\text {org }}$ is composed of a series of components with successively slower remineralization kinetic constants (Westrich and Berner, 1984; Middleburg, 1989). It may be that the unusually long (70 and $88 \mathrm{~cm}$ ) haloes observed in Sections 135-839A-5H-2 and -5H-4 (Fig. 10) are the result of turbidite emplacement during a period when hemipelagic sediment accumulation conditions were conducive to labile $\mathrm{C}_{\text {org }}$ persistence at depth. These long haloes have a gradation of color from top to bottom, varying from very pale (10YR $8 / 2$ ) or pale orange (10YR 7/2) directly beneath the turbidite base, through grayish orange (10YR 7/4) to dark grayish orange (10YR 7/6), and finally to dark yellowish orange (10YR 6/6) at the bases of the haloes. Although the geochemistry of such long haloes has not been investigated, it seems possible from their color variations that they may have been formed at former surfaces where labile $\mathrm{C}_{\text {org }}$ profiles declined more slowly than usual with depth.

The haloes discussed here have been ascribed to the reductive effects of reactive surficial $\mathrm{C}_{\text {org }}$ buried by turbidites. It is probable that they are generically related to other reduction phenomena observed in predominantly oxic sediments (e.g., the reduction spheroids often observed in red beds; see review by Hoffman, 1990). Unlike the haloes here, the nature of the reducing agent in rocks often has to be inferred. For example, to explain a $0.5-\mathrm{m}$ bleached section immediately underlying the Cretaceous/Tertiary boundary at one exposure, 


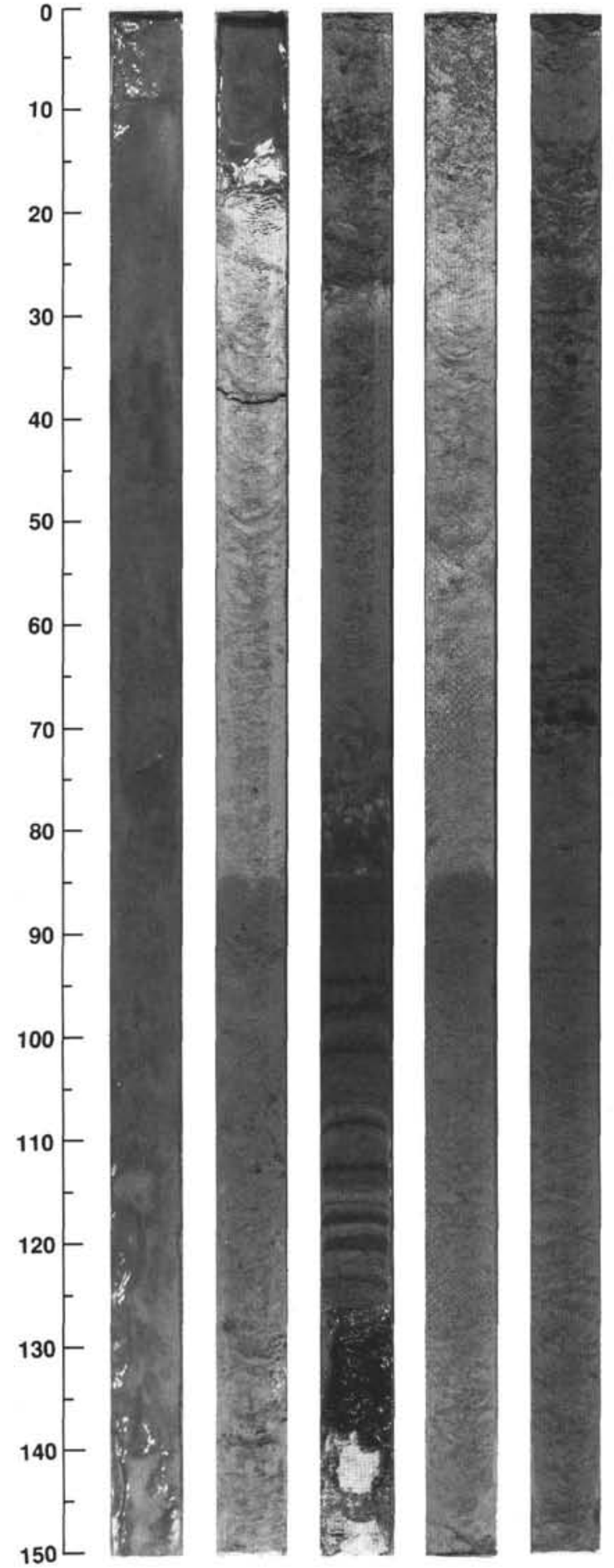

Figure 10. Photograph showing split core Sections 135-839A-5H-1 through $-5 \mathrm{H}-5$. Note the very long reduction haloes present in Sections $135-839 \mathrm{~A}-5 \mathrm{H}-2$ and $-5 \mathrm{H}-4$. The reduction halo in Section $135-839 \mathrm{~A}-5 \mathrm{H}-2$ is $70 \mathrm{~cm}$ thick and varies from pale orange (10YR $7 / 2$ ) directly beneath the overlying volcanic sand grading into grayish orange (10YR 7/4), to yellowish orange (10YR 7/6) to dark yellowish orange (10YR 6/6) down through the halo. The clayey nannofossil ooze below the halo is moderate yellowish brown (10YR 5/4) in color. The reduction halo in Section 135-839A-5H-4 is $88 \mathrm{~cm}$ thick and is yellowish gray $(5 \mathrm{Y} 7 / 2)$ grading to very pale orange (10YR $8 / 2$ ), to yellowish orange (10YR $7 / 6)$ to dark yellowish orange (10YR 6/6) down through the halo. The clayey nannofossil ooze below the halo is moderate yellowish brown (10YR 5/4) in color.
Lowrie et al. (1990) invoke "downwards infiltration of reducing waters resulting from the large quantity of organic matter produced by the extinctions at the K-T boundary." Advection or diffusion often also has to be invoked to supply sufficient reductant (electrons) to react with the large quantities of exotic redox-sensitive elements immobilized within reduction spheroids (Hoffman, 1990).

\section{CONCLUSIONS}

In the cores from six Leg 135 backarc sites, a bleached sediment color of variable length $(<1$ to $88 \mathrm{~cm})$ was observed immediately under 29 of 168 turbidite events, but nowhere else in the same cores. By analogy with studies elsewhere on brown clays, these light-colored sediments are identified as reduction haloes, caused by the burial of labile $\mathrm{C}_{\text {org }}$ at the former sediment surface by turbidite emplacement. The oxyhydroxides of $\mathrm{Mn}$ and $\mathrm{Fe}$ are then utilized as electron acceptors to remineralize this $\mathrm{C}_{\text {org }}$ in the absence of oxygen, and $\mathrm{Mn}$ and $\mathrm{Fe}$ have profiles of a characteristic shape within the haloes. Manganese is consistently at low levels and appears responsible for the color changes, whereas Fe has lowest values immediately under the turbidite, increases through a maximum, and then decines. The elements $\mathrm{Co}, \mathrm{Ni}$, and $\mathrm{Cu}$ are also present at lower levels in the haloes, although their concentration depth profiles are not identical with each other or with those for Mn. In contrast, V appears to have migrated into the halo sections and to have been retained there. The two halo examples selected for investigation underlay long ( $>3 \mathrm{~m}$ thick) turbidites, and as a result no elemental relocalization into the turbidites was observed. Haloes appear to be least common and to have the smallest thicknesses at sites where the redeposited sediments are either unusually coarse grained or are the result of catastrophic failure of steep basin margins. The absence of haloes, therefore, suggests that emplacement of the corresponding turbidites was erosive, and this is borne out by the nature of the turbidites and their geological settings.

\section{ACKNOWLEDGMENTS}

We thank Chris Mato, John Miller, and the staff at the ODP Gulf Coast Repository, College Station, Texas, for their assistance in sampling the Leg 135 sediment cores. Dr. Russ Merrill is also thanked for his patience and help in obtaining the quantitative color measurements using the ODP CIE LAB color system. We would also like to thank the Shipboard Scientific Party, the ODP technicians, and the SEDCO drilling crew of Leg 135, during which the data was collected. The paper was improved by comments by Drs. D.Z. Piper and R.E. Cranston, who reviewed the paper. Mike Conquer is thanked for producing the photographic prints.

\section{REFERENCES $*$}

Berner, R.A., 1981. A new geochemical classification of sedimentary environments. J. Sediment. Petrol., 51:359-365.

Breit, G.N., and Wanty, R.B., 1991. Vanadium accumulation in carbonaceous rocks: a review of geochemical controls during deposition and diagenesis. Chem. Geol., 91:83-97.

Cronan, D.S., Hodkinson, R.A., Harkness, D.D., Moorby, S.A., and Glasby, G.P., 1986. Accumulation rates of hydrothermal metalliferous sediments in the Lau Basin, S.W. Pacific. Geo.-Mar. Lett., 6:51-56.

Emerson, S.R., and Huested, S.S., 1991. Ocean anoxia and the concentrations of molybdenum and vanadium in seawater. Mar. Chem., 34:177-196.

Govindaraju, K., 1989. 1989 compilation of working values and sample description for 272 geostandards. Geostand. Newsl., 13:1-113.

Grant, J.A., 1986. The isocon diagram-a simple solution to Gresen's equation for metasomatic alteration. Econ. Geol., 81:1976-1982.

\footnotetext{
- Abbreviations for names of organizations and publication titles in ODP reference lists follow the style given in Chemical Abstracts Service Source Index (published by American Chemical Society).
} 
Grundmanis, V., and Murray, J.W., 1982. Aerobic respiration in pelagic marine sediments. Geochim. Cosmochim. Acta, 46:1101-1120.

Hodkinson, R.A., Cronan, D.S., Glasby, G.P., and Moorby, S.A., 1986. Geochemistry of marine sediments from the Lau Basin, Havre Trough and Tonga-Kermadec Ridge. N.Z. J. Geol. Geophys., 29:335-344.

Hoffman, B.A., 1990. Reduction spheroids from northern Switzerland: mineralogy, geochemistry and genetic models. Chem. Geol., 81:55-81.

Jarvis, I., and Higgs, N., 1987. Trace-element mobility during early diagenesis in distal turbidites: late Quaternary of the Madeira Abyssal Plain, N Atlantic. In Weaver, P.P.E., and Thomson, J. (Eds.), Geology and Geochemistry of Abyssal Plains. Geol. Soc. Spec. Publ. London, 31:179-214.

Kadko, D., 1985. Late Cenozoic sedimentation and metal deposition in the North Pacific. Geochim. Cosmochim. Acta, 49:651-661.

Kadko, D., Cochran, J.K., and Lyle, M., 1987. The effect of bioturbation and adsorption gradients on solid and dissolved radium profiles in sediments from the eastern equatorial Pacific. Geochim. Cosmochim. Acta, 51:16131623.

Krishnaswami, S., 1976. Authigenic transition elements in Pacific pelagic clays. Geochim. Cosmochim. Acta, 40:425-434.

Lewan, M.D., 1984. Factors controlling the proportionality of vanadium to nickel in crude oils. Geochim. Cosmochim. Acta, 48:2231-2238.

Li, Y.-H., 1981. Ultimate removal mechanisms of elements from seawater. Geochim. Cosmochim. Acta, 45:1659-1664.

Lowrie, W., Alvarez, W., and Asaro, F., 1990. The origin of the White Beds below the Cretaceous-Tertiary boundary in the Gubbio section, Italy. Earth Planet. Sci. Lett., 98:303-312.

Mazzullo, J.M., Meyer, A., and Kidd, R., 1987. New sediment classification scheme for the Ocean Drilling Program. In Mazzullo, J., and Graham, A.G. (Eds.), Handbook for Shipboard Sedimentologists. ODP Tech. Note, 8:4567.

Means, J.L., Crerar, D.A., Borcsik, M.P., and Duguid, M.P., 1978. Radionuclide adsorption by manganese oxides and implications for radioactive waste disposal. Nature, 274:44-47.

Middleburg, J.J., 1989. A simple rate model for organic matter decomposition in marine sediments. Geochim. Cosmochim. Acta, 53:1577-1581.

Middleburg, J.J., De Lange, G.J., and Van der Weijden, C.H., 1987. Manganese solubility control in marine pore waters. Geochim. Cosmochim. Acta, 51:759-763.

Moorby, S.A., Knedler, K.E., Glasby, G.P., Hodkinson, R.A., and Cronan, D.S., 1986. Lithology, colour, mineralogy and geochemistry of marine sediments of the Lau Basin, Havre Trough, and Tonga-Kermadec Ridge. N.Z. Oceanogr. Inst., Oceanogr. Field Rep., 27.

Müller, P.J., and Mangini, A., 1980. Organic carbon decomposition rate in sediments of the Pacific manganese nodule belt dated by ${ }^{230} \mathrm{Th}$ and ${ }^{231} \mathrm{~Pa}$. Earth Planet. Sci. Lett., 51:94-114.
Parson, L., Hawkins, J., Allan, J., et al., 1992. Proc. ODP, Init. Repts., 135: College Station, TX (Ocean Drilling Program).

Piper, D.Z., 1988. The metal oxide fraction of pelagic sediment from the equatorial North Pacific Ocean: a source of metals in ferromanganese nodules. Geochim. Cosmochim. Acta, 52:2127-2145.

Piper, D.Z., Rude, P.D., and Monteith, S., 1987. The chemistry and mineralogy of haloed burrows in pelagic sediment at DOMES Site A: the equatorial North Pacific. Mar. Geol., 74:41-55.

Postma, D., 1985. Concentration of $\mathrm{Mn}$ and separation from Fe in sedimentsI. Kinetics and stoichiometry of the reaction between birnessite and dissolved $\mathrm{Fe}$ (II) at $10^{\circ} \mathrm{C}$. Geochim. Cosmochim. Acta, 49:1023-1033.

Rabouille, C., and Gaillard, J.-F., 1991. Towards the EDGE: early diagenetic explanation. A model depicting the early diagenesis of organic matter, $\mathrm{O}_{2}$, $\mathrm{NO}_{3}, \mathrm{Mn}$ and $\mathrm{PO}_{4}$. Geochim. Cosmochim. Acta, 55:2511-2525.

Reich, V., 1990. Calcareous ooze, volcanic ash, and metalliferous sediments in the Quaternary of the Lau and North Fiji basins. Geol. Jahrb., D92:109-162.

Reich, V., Marchig, V., Sunkel, G., and Weiss, W., 1990. Hydrothermal and volcanic input in sediments of the Lau back-arc basin, S.W. Pacific. Mar. Mining, 9:183-203.

Thomson, J., Carpenter, M.S.N., Colley, S., Wilson, T.R.S., Elderfield, H., and Kennedy, H., 1984. Metal accumulation rates in northwest Atlantic pelagic sediments. Geochim. Cosmochim. Acta, 48:1935-1948.

Thomson, J., Colley, S., Higgs, N., Hydes, D.J., Wilson, T.R.S., and Sørensen, J., 1987. Geochemical oxidation fronts in NE Atlantic distal turbidites and their effects on the sedimentary record. In Weaver, P.P.E., and Thomson, J. (Eds.), Geology and Geochemistry of Abyssal Plains. Geol. Soc. Spec. Publ. London, 31:167-178.

Thomson, J., Higgs, N.C., and Colley, S., 1989. A geochemical investigation of reduction haloes developed under turbidites in brown clay. Mar. Geol., $89: 315-330$

Totland, M., Jarvis, I., and Jarvis, K.E., 1992. An assessment of dissolution techniques for the analysis of geological samples by plasma spectrometry. Chem. Geol., 95:35-62.

Trefry, J.H., and Metz, S., 1989. Role of hydrothermal precipitates in the geochemical cycling of vanadium. Nature, 342:531-533.

Westrich, J.T., and Berner, R.A., 1984. The role of sedimentary organic matter in bacterial sulfate reduction: the G model tested. Limnol. Oceanogr., 29:236-249.

Date of initial receipt: 2 July 1992

Date of acceptance: 2 November 1992

Ms 135SR-109 